\title{
MODERN CONSTRUCTION SOLUTIONS FOR PRESTRESSED CABLE DOMES AND WAYS TO IMPROVE THEM
}

\author{
Kolomiychuk G.P., PhD., Assistant Professor, \\ gp11k1m@gmail.com, ORCID: 0000-0003-4484-7791 \\ Kolomiichuk V.G., postgraduate student, \\ slavikkolomy@gmail.com \\ Kolomiichuk V.G., student, \\ veronika.kolomy@gmail.com \\ Odessa State Academy of Civil Engineering and Architecture
}

\begin{abstract}
To create fundamentally new innovative large-span structures of buildings and structures coverings, modern design solutions of prestressed cable domes of the Tensegrity type are considered. The service life of the first built Tensigrity domes is only 35 years. These are fairly new, effective structures that require careful study and use of modern scientific approaches for their design using software systems, since their work under load and the construction process are quite complex. The design analysis and erection of self-stressed structures is based on the invention of an equilibrium structure, the so-called tensegrity form. The search for the shape is multidimensional and consists of the stage of computational analysis of a self-stressed dome for the equilibrium position of elements and their nodes, selection of the most stable and rigid structure, as well as taking into account possible unfavorable loads during operation and the initial load in the elements from the application of prestressing. To determine the shape of cable domes, a nonlinear programming problem with given axial forces is formulated, which can be considered as the problem of minimizing the difference in the total strain energy between the elements of the cables and struts under constraints on the compatibility conditions. The first step in calculating the prestressing of a cable dome is to assess the feasibility of its geometry. The possibility of forming a cable dome of negative Gaussian curvature is considered and a method for calculating the prestressing for this new shape is investigated. The proposed method is effective and accurate in determining the allowable prestressing for a cable dome with negative Gaussian curvature and can be used for other types of prestressed structures. The new directions for the development of effective constructive solutions for large-span coatings are presented, including a suspended-dome structure, which combines the advantages of a mesh shell and a cable dome. Special attention should be paid to experimental studies on models of tensegrity domes, the results of which demonstrate the positive and negative aspects of the behavior of structures under load, the process of their erection, as well as the possibility of control and restoration during operation.
\end{abstract}

Keywords: self-tensioned cable dome, tensegrity principle, constructive solutions, prestressing, shape search.

Introduction. Today, improvements in the field of construction include not only the modernization of construction methods and the use of effective materials, but also the creation of fundamentally new innovative structures of construction. Of course, such structures include structures based on the principle of self-tensioned structures, or the principle of tensegrity (from the English Tension integrity - combination by tension). The design analysis and erection of self-stressed type structures is based on the invention of an equilibrium structure, the so-called form of tensegrity. The search for the shape of the structure includes the selection of the most efficient design of the main Tensegrity modules or the entire structure of the dome. The term "shape search" only sounds simple at first sight, but it is multidimensional and consists of the stage of computational analysis of a selfstressed dome for the equilibrium position of elements and their nodes, selection of the most stable and rigid structure, as well as taking into account possible unfavorable loads during operation and initial load in elements from prestressing. 
Analysis of recent research and publications. Tensegrity-type prestressed cable domes are structures that are very convenient for covering large spans due to the fact that a relatively small number of elements are required to form a structure, their high level of factory readiness and ease of assembly. There are two main approaches to the formation of tensegrity domes: a radial spatial network (Geiger, Fig. 1, a) and a triangulated spatial network (Levy, Fig. 1, b). The article [1] investigates the parameters of the network geometry on the behavior and structural efficiency of Tensegrity domes. In the triangulated design, the complexity of the redistribution of the initial prestressing of the central zone is noted. The stress distribution in the structures of tensegrity domes after the application of various loads did not change significantly compared to the case of the main load, with the exception of the radial structure, where, upon application of a wind load, there was a significant decrease in tensile forces and external tension of the hoop occurred, as well as a linear decrease in the intensity of the tension force in diagonal cables from the center to the periphery of the structure.

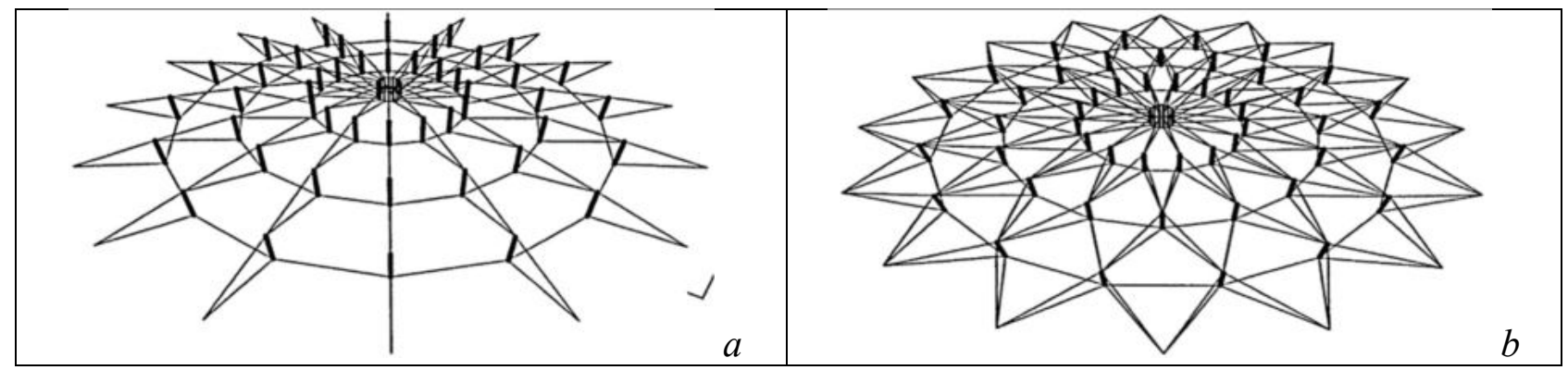

Fig.1. Formation of the structure of the Tensegrity dome: $a$ - Geiger; $b$ - Levy

The first two radial-type Tensegrity domes were built in 1986 in Korea for the Olympic Games [2]. Fencing arena dome with two hoops $(\mathrm{N}=2), 16$ polygon sides $(\mathrm{n}=16)$, span $\mathrm{L}=394$ feet $(120)$, rise $r=32$ feet and depth $d=40$ feet (the dome is designated N2: n16: L400: $r$ / L0.08: $d /$ L0.10). The dome of the arena for gymnastics with a span of $\mathrm{L}=305$ feet $(93 \mathrm{~m})$.

There are only six radial-type domes with flexible cover membranes. The first such dome in the United States, the University of Illinois Redbird Arena, was built in 1989. The dome has an elliptical plan $(91 \times 77 \mathrm{~m})$ with one hoop and 32 polygon sides, i.e. N1: $\mathrm{n} 32$. The ridge profile visually emphasizes the tops created by their upper ends and therefore does not have a smooth domed appearance.

The Tropicana Dome in St. Petersburg, Florida, was built in 1990 and has the largest span to date $(210 \mathrm{~m})$ with three hoops, each of which forms a 24-sided polygon, that is, N3: $\mathrm{n} 24$. The dome is unique in that its inclination is 6 degrees relative to the horizon.

To determine the shape of cable domes, a nonlinear programming problem with given axial forces was formulated, which can be considered as the problem of minimizing the difference in the total deformation energy between the elements of the cables and struts under constraints on the compatibility conditions [3]. Optimality conditions for the problem are obtained that ensure the coincidence of the optimal solution with the self-balanced configuration of the cable dome with the given axial forces of the rods. A numerical example shows that a set of admissible axial forces can be found using the proposed algorithm. The problem is solved with the help of well-developed existing nonlinear programming software based on the primary double interior points method, and the task is only to enter the geometry and material information of the rope dome.

The first step in calculating the prestressing of a cable dome is to assess the feasibility of its geometry [4]. The paper proposes a simple iterative process called the unbalanced force iteration method to evaluate the feasibility of the geometry and find the self-stressing modes of the cable dome structure. For structures with invalid geometry, the required nodal coordinates can be found by stepby-step use of the unbalanced force iteration method, which changes the nodal positions by landslides to balance the forces. The new configurations of circular or asymmetric shapes proposed in the work provide an alternative choice for designing cable domes with a variety of architectural purposes.

To enrich the design forms of cable domes and meet the needs of architecture, the article [5] considers the possibility of forming a cable dome of negative Gaussian curvature and investigates a 
method for calculating the prestressing for this new shape. A numerical model of the cable dome was built to illustrate the feasibility of the new shape. The method proposed in this article is effective and accurate in determining the allowable prestressing for a cable dome with negative Gaussian curvature and can be used for other types of prestressed structures. A negative Gaussian curvature cable dome has better structural rigidity than a corresponding cable network design and is more stable than a traditional Geiger dome. The possibility of creating other new combined structures with a large span of negative Gaussian curvature should be investigated to further expand the use of structures in practical projects.

In [6], a review of modern large-span roofs consisting of an upper single-layer lattice dome reinforced with a lower tensegrity system is made. The suspended-dome design combines the advantages of a trellis shell and cable domes. The horizontal reactions that occur in the suspendeddome structure can be reduced by careful placement of the prestressing cables. This is due to the fact that with the help of prestressed cables, it is possible to change the value and distribution of stresses in the structure, thereby increasing its rigidity. The most common shape of the plan for a suspended dome roof structure is round, but elliptical and polygonal are also possible. Positive results indicate the need to use carbon fiber reinforced polymer cables for the structure of the suspended dome system instead of traditional steel cables.

Goal and tasks. The purpose of this study is to select the forms of rational design solutions for metal tensegrity domes, to identify the features of the application of prestressing during construction and their behavior under the influence of unfavorable loads, for the accumulation of factual information for further improvement.

Materials and research methods. Self-stressed rope domes are an integral part of unique buildings and structures. Constructive solutions of the constructed tensegrity domes are considered, as well as new experimental and theoretical studies of their behavior under load.

Due to the small number of similar design solutions of tensegrity domes, only those that are in the range of this study were selected for inspection, and are promising for further improvement and development.

Research results. New designs of tensigrity domes on a circular plan were investigated in [6]: fig. 2, $a$ - an improved Geiger dome with additional annular tension cables; fig. 2,b - in this structure, diagonal cables are connected in such a way that two cables run on top of each outer rack. One of these cables is connected to the bottom of the inner rack, which is to the left of the outer rack, and the other cable is connected to the inner rack, which is to the right of the outer rack; fig. 2,c-the posts take a reverse V-shape and the diagonal cables are connected; fig. 2, $d$ - racks appear in groups of four elements connected together in the circumferential direction.

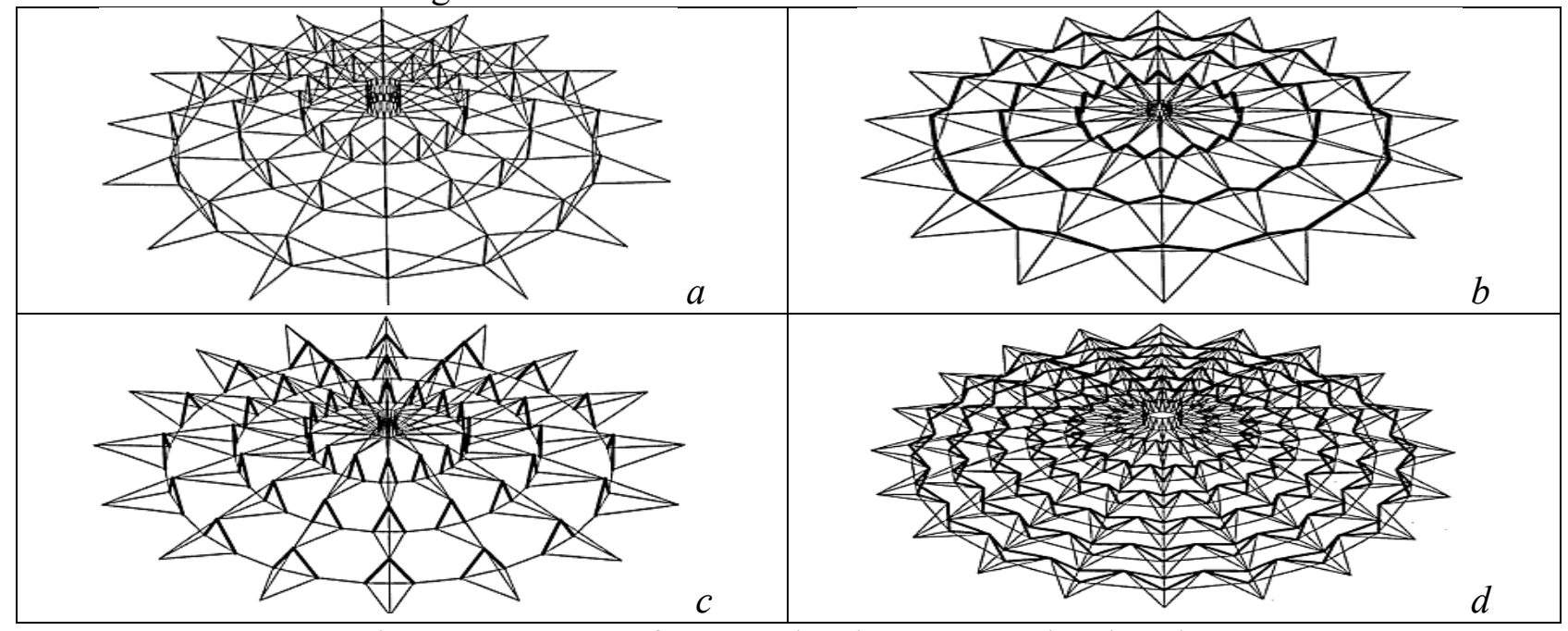

Fig.2. New types of Tensegrity domes on a circular plan

Calculations of new types of domes for the action of various types of loads are performed. The largest vertical deflection of the dome (Fig. 2,a) is $821 \mathrm{~mm}$, which occurs with an unbalanced snow 
load, and more lateral movement occurs - $90 \mathrm{~mm}$. For domes fig. 2,b (Fig. 2,c) the results are 1027 (1084) $\mathrm{mm}$ and 190 (434) mm, respectively. The most rigid dome was shown in Fig. 2,d.

The article [8] proposes new forms of cable domes, complementing the existing ones, and discusses their geometric feasibility. The bird's nest shape is another new shape inspired by the National Stadium of China in Beijing, built for the 2008 Olympics. Its configuration is characterized by a large central opening, the edge of which is formed by internal circular cables. Thanks to the open hole, the bird's nest shape is suitable for coverings with a large center hole. If it is necessary to cover a non-circular shape in plan, such as an elliptical or rectangular shape in plan, different shapes can be adopted in different regions.

The article [9] presents a study of a new type of cable dome by Levi Tensegrity (Fig. 3). For the first time, its topology is introduced and the initial finding of the shape is discussed. Static and dynamic analysis shows the feasibility of using a tensegrity torus as a ring support. The new Levi dome with tensegrity used as an annular support is divided into 12 latitudinal sections and has 3 annular hoops. Tensegrity torus consists of 12 segments with geometric parameters $R_{t}=50 \mathrm{~m}$ and $r=$ $4 \mathrm{~m}$.

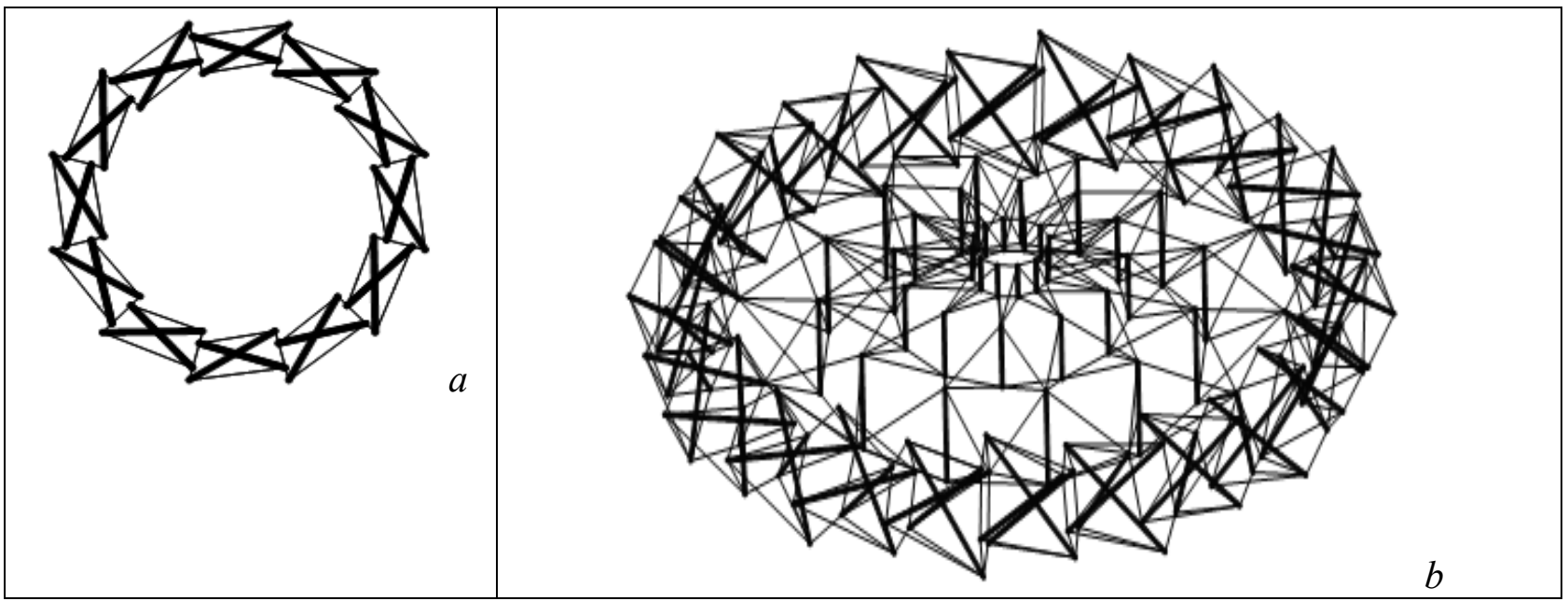

Fig.3. Levi dome with tensegrity torus: $a$ - ring support plan; $b$-general form

New designs of tensigrity domes on an elliptical plan (Fig. 4) with various geometric networks proposed in [10]. The author compares the proposed options with the prototype - Georgia Dome (table 1). The table shows the mass of steel obtained with the reduction of the cost of metal cables to steel sections. Table 1 shows that all Tensegrity domes exhibit low steel consumption. For Type 1, the flow rates are even lower than in the Georgia Dome, but the dome is less rigid. Type 1 and Georgia Dome maximum allowable vertical movements, approximately $1 / 227$ to $1 / 272$ short span, are acceptable. This proves that the concept of designing quasi-elliptical domes with reinforcement of the center section and simplification of semicircular sectors is effective.
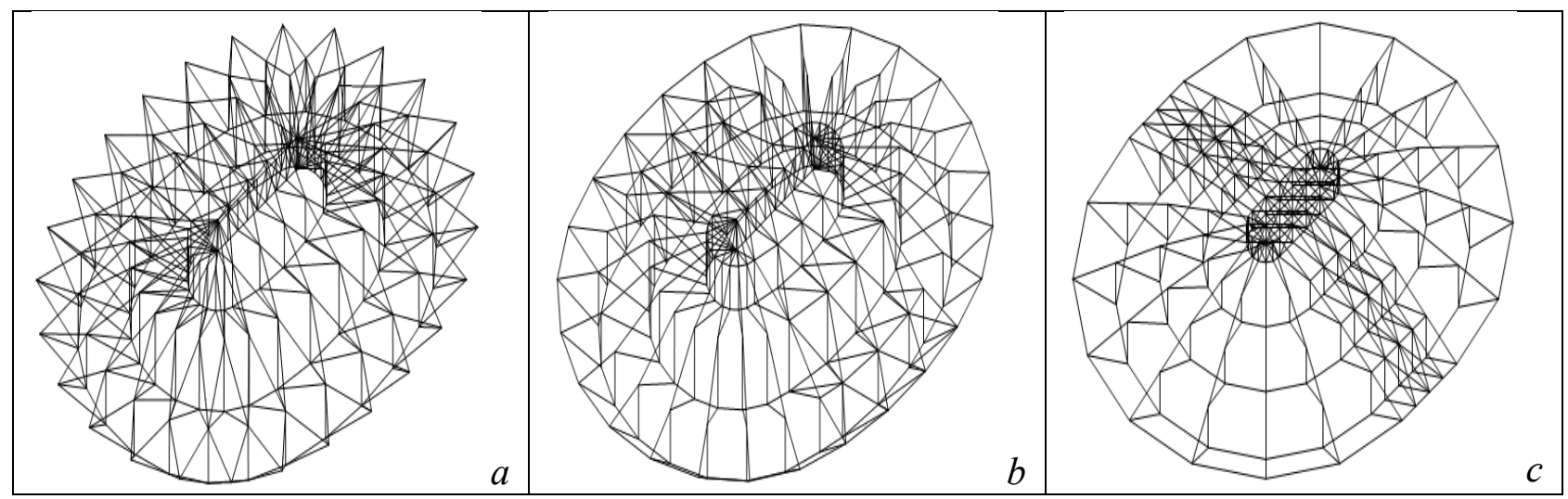

Fig.4. Dome on the elliptic plan: $a$-prototype - Georgia Dome; $b$-type $1 ; c$-type 2

Comparison of Tensegrity domes on an elliptical plan 


\begin{tabular}{|c|c|c|c|}
\hline Dome structure & $\begin{array}{c}\text { Weight of steel, } \\
\mathrm{kg} / \mathrm{m}^{2}\end{array}$ & $\begin{array}{c}\text { Reduced weight of steel, } \\
\mathrm{kg} / \mathrm{m}^{2}\end{array}$ & $\begin{array}{c}\text { Maximum } \\
\text { deflection, } \mathrm{mm}\end{array}$ \\
\hline Georgia Dome & 23,3 & 37,8 & 706 \\
\hline Type 1 & 20,5 & 33,4 & 846 \\
\hline Type 2 & 31,5 & 42,2 & 407 \\
\hline
\end{tabular}

The design of a double strut cable dome (Fig. 5) was considered in [11]. This design has good stability and is easy to manufacture. To investigate the construction method and static characteristics, an experimental model with a diameter of $6 \mathrm{~m}$ was developed. From the equations of the nodal equilibrium, formulas were derived for the distribution of prestress, taking into account its own weight. In the process of shaping the double strut cable dome, two construction methods have been adopted, namely high altitude stacking and integral lift, with control of the internal strength of the cable strut components and the deformation of the structure. The results of full-scale loading and loading tests on half of the dome are compared with the results of calculations by the finite element method. The model test results are in good agreement with the results of the finite element analysis.

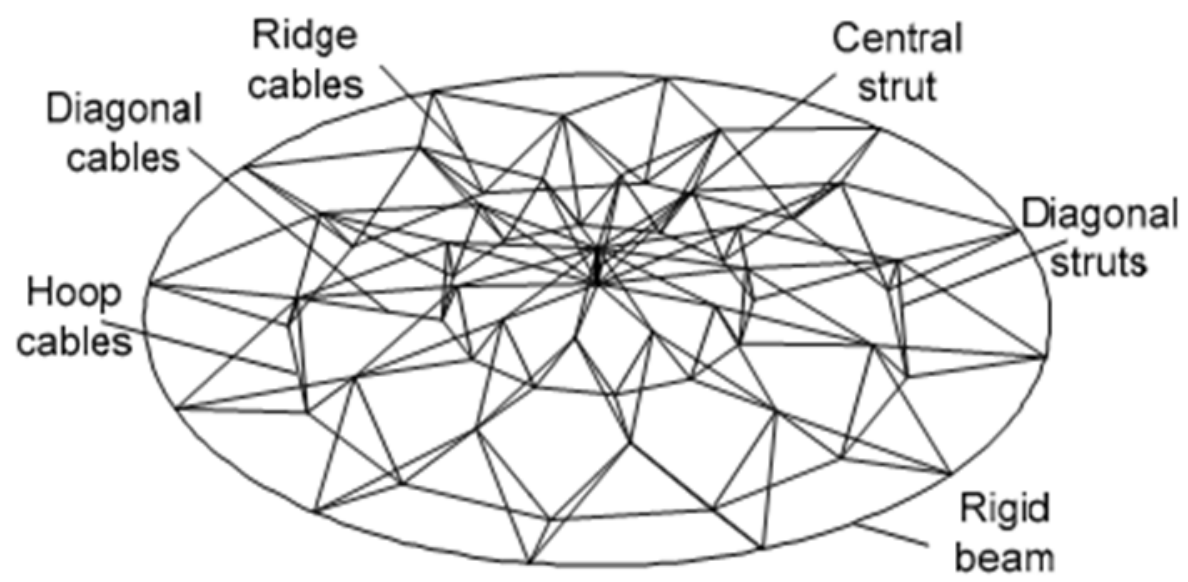

Fig.5. Model dome with double strut

The application of prestressing is one of the main elements of the flattening of the cable dome. However, it is difficult to ensure that the calculated prestressing of the cables will be accurately applied to the structure on site due to the introduction of various types of errors during construction [12]. Thus, it is necessary to propose an effective construction management method so that the construction team regulates the necessary pre-tensioning of the cables multiple times. The article presents a sensitivity analysis method based on Spearman's rank correlation, where random errors are simulated by the Monte Carlo method to solve the production error problem. On a numerical model of a cable dome with a diameter of $62 \mathrm{~m}$, the sensitivity of the influence of errors in the manufacture of supports and cable length on the design characteristics is analyzed. A model of a cable dome with a diameter of $6 \mathrm{~m}$ has been developed and tested (Fig. 6). The experimental results are consistent with the theoretical ones, which prove that the theory of analysis is correct and the method of control is effective.

In studies [13-17], recently developed adaptive cable domes of the Levy shape (Fig. 7, Fig. 8) were presented, consisting of one and seven action elements, which have the ability to change their configuration of rigidity and stress properties in order to adapt their behavior to current load conditions. These new structures contain sensors that detect forces in systems and elements of action that regulate their stiffness and stress state, making the structure more rigid or flexible depending on the actual applied load. The results of experimental and theoretical analysis are compared. The tests confirmed the functionality of the developed adaptive systems and the suitability of the proposed equipment, software, computational models and control commands. Multipurpose search is used to select control commands for these active structures. An appropriate tool for optimizing the control process is the use of genetic algorithms. 


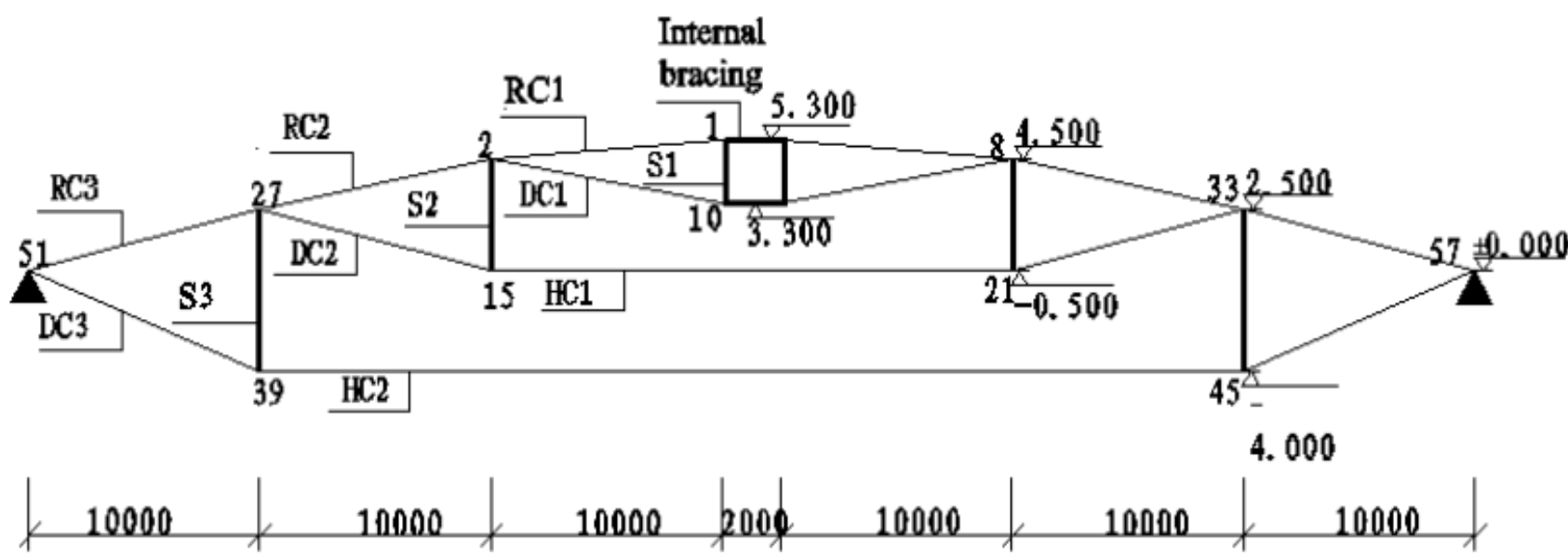

Fig.6. Section along the axis of symmetry of the Tensegrity dome model

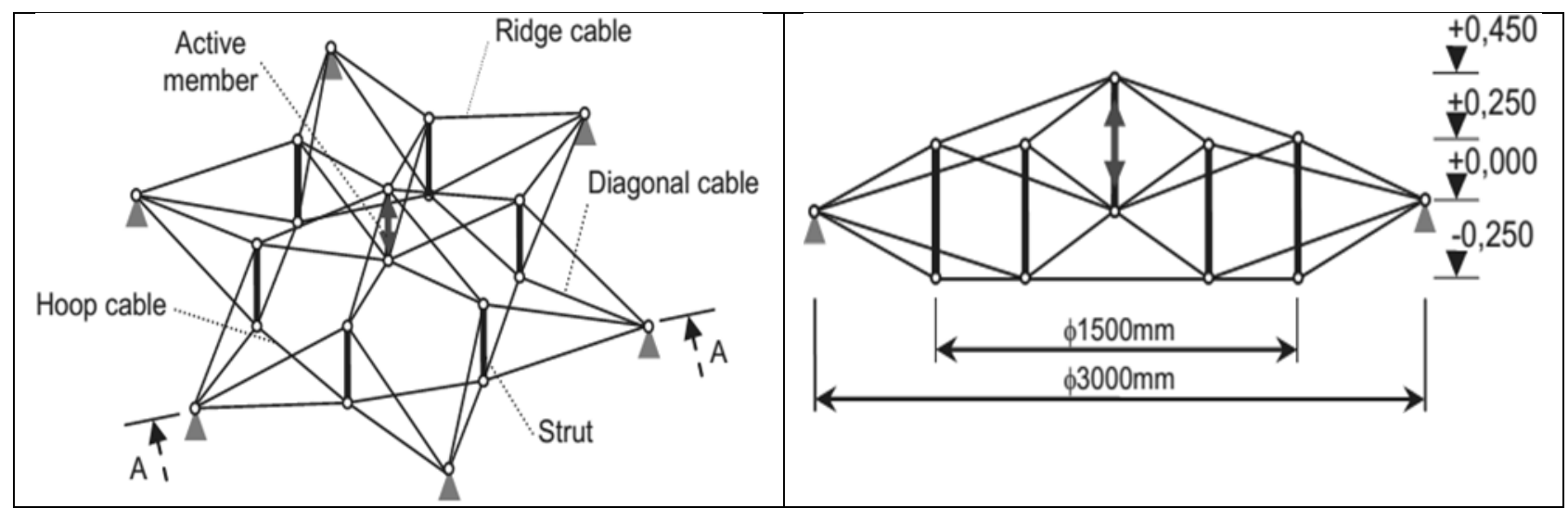

Fig.7. Cable dome model geometry: water park view; section A-A

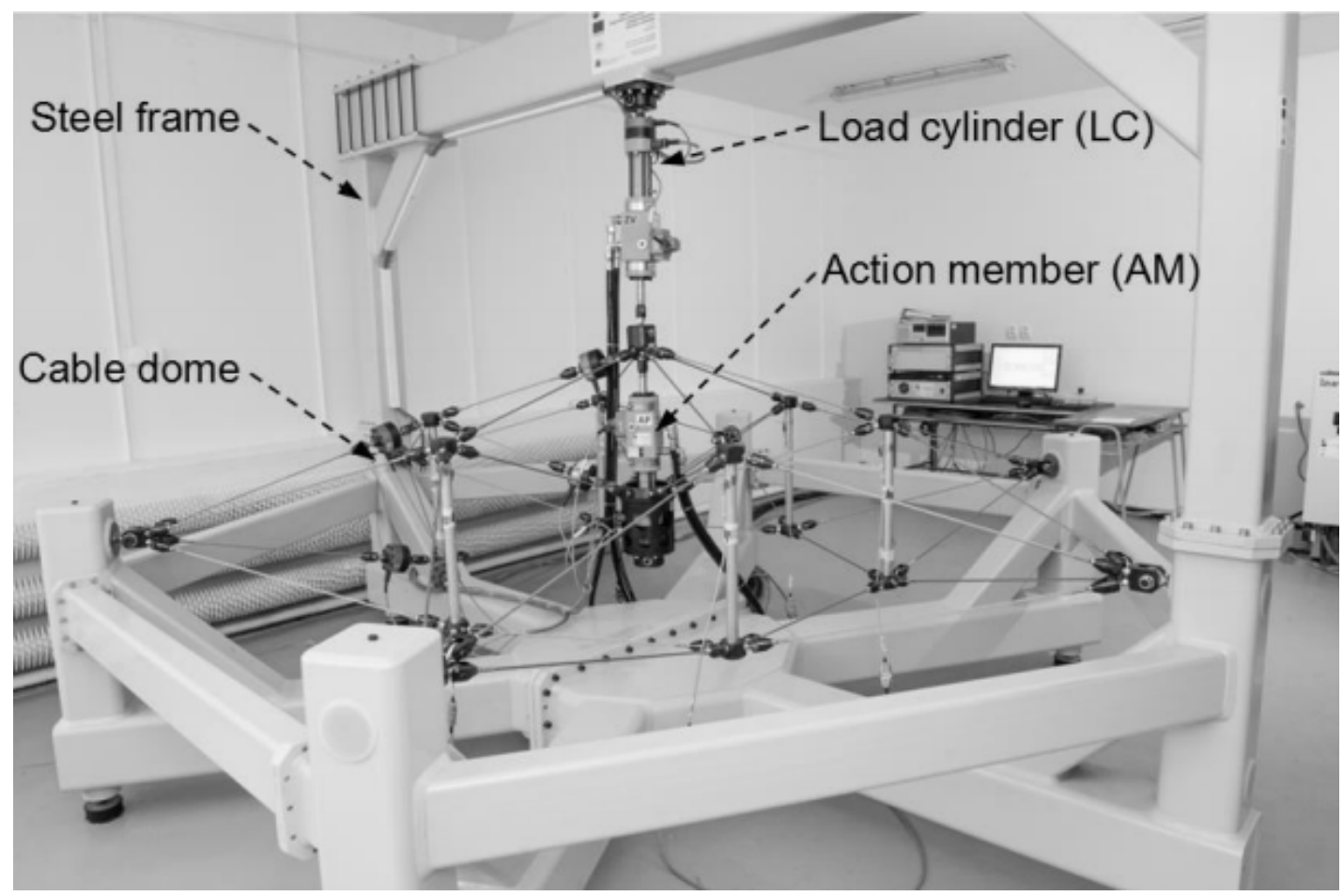

Fig.8. Adaptive cable dome model mounted in a self-supporting frame

Summary. To achieve the goal, the choice of forms of rational design solutions for metal domes-tensegrity was made, as well as directions for improving their design using software systems. 
New approaches to the application of prestressing during the construction of cable domes, as well as adaptive models that allow restoring the prestressing in the cables are presented.

For further research, it is important to investigate the deviations in the geometry of cable domes, which they receive during construction, and to make calculations with initial imperfections.

\section{References}

[1] Nenadović A. Development, Characteristics and Comparative Structural Analysis of Tensegrity Type Cable Domes / A. Nenadović // Spatium International Review, 2010. - No. 22. - P. 5766. DOI: $10.2298 /$ SPAT1022057N · Source: DOAJ

[2] Sudarshan Krishnan. Prestressed cable domes: structural behavior and design: Dissertation submitted in partial fulfillment of the requirements for the degree of Doctor of Philosophy in Civil Engineering in the Graduate College of the University of Illinois at Urbana-Champaign. - Illinois, 2015.

[3] Ohsaki M. Form-finding of cable domes with specified stresses by using nonlinear programming / M. Ohsaki, Y. Kanno // Kyoto University, Sakyo, Kyoto 606-8501, Japan. http://www.se-lab.archi.kyoto-u.ac.jp/ohsaki/pdf/c0302.pdf.

[4] Qing M. Step-by-Step Unbalanced Force Iteration Method for Cable-Strut Structure with Irregular Shape / M. Qing // Engineering Structures, 2018. - Vol. 177. - P. 331-344. http://hdl.handle.net/2433/242991

[5] Guo J. Negative Gaussian Curvature Cable Dome and Its Feasible Prestress Design // Journal of Aerospace Engineering, 2016. - Vol. 29(3). - P. 1-9. 5525.0000585

[6] Olofin I. Suspen-dome system: a fascinating space structure / I. Olofin, R. Liu // The Open Civil Engineering Journal, 2017. - Vol. 11. - P. 131-142. DOI:10.2174/1874149501711010131

[7] El-lishani S.S. Cable domes and their stability: Dissertation submitted for the degree of Doctor of Philosophy Space Structures Research Centre Department of Civil Engineering University of Surrey, 2004.

[8] Yuan X. Prestress design of cable domes with new forms / X. Yuan, L. Chen, S. Dong // International Journal of Solids and Structures, 2007. - Vol. 14. - P. 2773-2782. doi:10.1016/j.ijsolstr.2006.08.026

[9] Yuan X. A New Tensegrity Module - "Torus"/ X. Yuan, Z. Peng, S. Dong, B. Zhao // Advances in Structural Engineering, 2008. - Vol. 11. - No. 3. - P. 243-251.

[10] Fu F. Structural behavior and design methods of Tensegrity domes / F. Fu // Journal of Construction Steel Research, 2005. - Vol. 61(1). - P. 23-35. doi:10.1016/j.jcsr.2004.06.004

[11] Zhang A. Experimental study on the construction shape-forming process and static behaviour of a double strut cable dome / A. Zhang, C. Sun, Z. Jiang // Journal of Zhejiang UniversitySCIENCE A (Applied Physics \& Engineering), 2018. - Vol. 19(3). - P. 225-239. https://doi.org/10.1631/jzus.A1700071

[12] Zhang J. Manufacture Errors Analysis and Control of Cable Dome / J. Zhang, K. Sun, Z. Wang // The Open Civil Engineering Journal, 2011. - Vol. 5. - P. 75-81.

[13] Kmet S. Analysis of adaptive light-weight structures / S. Kmet, P. Platko, M. Mojdis // Procedia Engineering, 2012. - Vol. 40. - P. 199-204. doi: 10.1016/j.proeng.2012.07.080

[14] Kmet S. Adaptive Cable Dome / S. Kmet, M. Mojdis // Journal of Structural Engineering ASCE, 2015. - Vol. 141(9). https://doi.org/10.1061/(ASCE)ST.1943-541X.0001189

[15] Cauner P. Experimental and theoretical analysis of cable dome / P. Cauner, S. Kmet, M. Mojdis // Proceedings of the 7th GACM Colloquium on Computational Mechanics for Young Scientists from Academia and Industry October 11-13, 2017 in Stuttgart, Germany.

[16] Cauner P. Analysis of cable dome under various initial conditions / P. Cauner, S. Kmet // JCEEA, 2018. - T. XXXV. - V. 65 (1/18). - P. 5-12. DOI:10.7862/rb.2018.1

[17] Kmet S. Analyses of cable domes with action members / S. Kmet, P. Cauner // Experimental study on the construction shape-forming process and static behaviour of a double strut cable 
dome / A. Zhang, C. Sun, Z. Jiang // MultiScience - XXXIII. microCAD International Multidisciplinary Scientific Conference University of Miskolc, 23-24 May, $2019 . \quad$ DOI: 10.26649/musci.2019.001

\title{
СУЧАСНІ КОНСТРУКТИВНІ РІШЕННЯ ПОПЕРЕДНЬО НАПРУЖЕНИХ ТРОСОВИХ КУПОЛІВ І ШЛЯХИ ЇХ ВДОСКОНАЛЕННЯ
}

\author{
Коломійчук Г.П., к.т.н., доцент, \\ gp11klm@gmail.com, ORCID: 0000-0003-4484-7791 \\ Коломійчук В.Г., аспірант, \\ slavikkolomy@gmail.com \\ Коломійчук В.Г., студентка, \\ veronika.kolomy@gmail.com \\ Одеська державна академія будівництва та архітектури
}

\begin{abstract}
Анотація. Для створення принципово нових інноваційних великопролітних конструкцій покрить будівель та споруд розглянуто сучасні конструктивні рішення попередньо напружених тросових куполів типу тенсегріті. Термін експлуатації перших побудованих куполів-тенсігріті складає лише 35 років. Це досить нові, ефективні конструкції і потребують ретельного вивчення та використання сучасних наукових підходів для їх проектування 3 застосуванням програмних комплексів, так як їх робота під дією навантаження та процес будівництва досить складні. Розрахунковий аналіз і зведення конструкцій самонапруженого типу базується на винаході рівноважної конструкції, так званої форми тенсегріті. Пошук форми багатовимірний і складається з етапу розрахункового аналізу самонапруженого куполу на рівноважне положення елементів i їх вузлів, вибору найбільш стійкої і жорсткої конструкції, а також урахування можливих невигідних навантажень під час експлуатації i початкового навантаження в елементах від прикладення попереднього напруження. Для визначення форми тросових куполів сформульовано завдання нелінійного програмування 3 заданими осьовими силами, яке можна розглядати як завдання мінімізації різниці повної енергії деформації між елементами тросів і стійками при обмеженнях на умови сумісності. Першим кроком для розрахунку попереднього напруження тросового куполу $\epsilon$ оцінка здійсненності його геометрії. Розглядається можливість формування тросового куполу негативної Гауссової кривизни і досліджується метод розрахунку попереднього напруження для цієї нової форми. Запропонований метод є ефективним і точним при визначенні допустимого попереднього напруження для тросового куполу 3 негативною Гауссовою кривизною, i його можна використовувати для інших типів попередньо напружених конструкцій. Наведені нові напрями розвитку ефективних конструктивних рішень великопролітних покрить, серед яких підвісно-купольна конструкція, що поєднує в собі переваги гратчастої оболонки і тросових куполів. Особливої уваги заслуговують експериментальні дослідження на моделях куполів-тенсегріті, результати яких демонструють позитивні і негативні сторони поведінки конструкцій під дією навантажнення, процес їх зведення, а також можливість контролю та відновлення під час експлуатації.
\end{abstract}

Ключові слова: самонапружений тросовий купол, принцип тенсегріті, конструктивні рішення, попереднє напруження, пошук форми. 


\title{
СОВРЕМЕННЫЕ КОНСТРУКТИВНЫЕ РЕШЕНИЯ ПРЕДВАРИТЕЛЬНО НАПРЯЖЕННЫХ ТРОСОВЫХ КУПОЛОВ И ПУТИ ИХ СОВЕРШЕНСТВОВАНИЯ
}

\author{
Коломийчук Г.П., к.т.н., доцент \\ gp11klm@gmail.com, ORCID: 0000-0003-4484-7791 \\ Коломийчук В.Г., аспирант \\ slavikkolomy@gmail.com \\ Коломийчук В.Г., студентка \\ veronika.kolomy@gmail.com \\ Одесская государственная академия строительства и архитектуры
}

\begin{abstract}
Аннотация. Для создания принципиально новых инновационных большепролетных конструкций покрытий зданий и сооружений рассмотрены современные конструктивные решения предварительно напряженных тросовых куполов типа тенсегрити. Срок эксплуатации первых построенных куполов-тенсигрити составляет всего 35 лет. Это достаточно новые, эффективные конструкции которые требуют тщательного изучения и использования современных научных подходов для их проектирования с применением программных комплексов, так как их работа под действием нагрузки, и процесс строительства достаточно сложные. Расчетный анализ и возведение конструкций самонапряженного типа базируется на изобретении равновесной конструкции, так называемой формы тенсегрити. Поиск формы многомерный и состоит из этапа расчетного анализа самонапряженного купола на равновесное положение элементов и их узлов, выбора наиболее устойчивой и жесткой конструкции, а также учета возможных невыгодных нагрузок во время эксплуатации и начальной нагрузки в элементах от приложения предварительного напряжения. Для определения формы тросовых куполов сформулирована задача нелинейного программирования с заданными осевыми силами, которую можно рассматривать как задачу минимизации разницы полной энергии деформации между элементами тросов и стойками при ограничениях на условия совместности. Первым шагом для расчета предварительного напряжения тросового купола является оценка осуществимости его геометрии. Рассматривается возможность формирования тросового купола негативной Гауссовой кривизны и исследуется метод расчета предварительного напряжения для этой новой формы. Предложенный метод является эффективным и точным при определении допустимого предварительного напряжения для тросового купола с отрицательной Гауссовой кривизной, и его можно использовать для других типов предварительно напряженных конструкций. Приведенные новые направления развития эффективных конструктивных решений большепролетных покрытий, среди которых подвесная-купольная конструкция, сочетающая в себе преимущества сетчатой оболочки и тросового купола. Особого внимания заслуживают экспериментальные исследования на моделях куполов-тенсегрити, результаты которых демонстрируют положительные и отрицательные стороны поведения конструкций под действием нагрузки, процесс их возведения, а также возможность контроля и восстановления при эксплуатации.
\end{abstract}

Ключевые слова: самонапряженный тросовый купол, принцип тенсегрити, конструктивные решения, предварительное напряжение, поиск формы. 